\section{SHOPPING FOR IDENTITY: the} marketing of ethnicity

\author{
De Marilyn Halter \\ New York: Schocken Books, 2000. 140 p.
}

Por Ana Cristina Braga Martes, Professora do Departamento de Fundamentos Sociais e Jurídicos da Administração da FGV-EAESP. E-mail: acbmartes@fgvsp.br

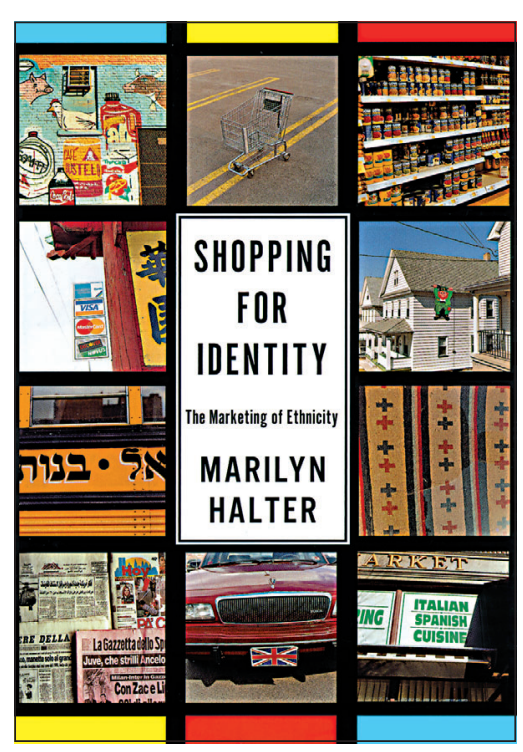

tensão do eu, e isto inclui sua própria identificação étnica" (p. 7).

O contexto sociocultural - no qual se insere a expansão do consumo de bens que fazem alusão aberta à etnicidade nos Estados Unidos - tem seu marco fundamental na deflagração dos movimentos de direitos civis nos anos 60. A partir de então, a atitude assimilacionista vem cedendo lugar à valorização do background étnico, reforçado pela nova onda de imigrantes que lá chegou nas décadas seguintes. Mas a autora não cai na armadilha de interpretar o apelo e a valorização da etnicidade como uma manifestação de autenticidade cultural nem como uma tábua de salvação ou possível refúgio das "minorias". Por outro lado, tal valorização também não é explicada por um tipo de racionalidade econômica manipulando a cultura e o consumo. O que Halter vai assinalar é a maneira como marketing e cultura podem resultar em casamentos interessantes porque favorecem igualmente a ambos. Afinal, como comenta a autora, transformar a cultura em mercadoria sempre foi uma das características do capitalismo, resultado inevitável de uma sociedade de mercado. Mas as relações entre ambos é muito mais complexa, especialmente em se tratando de etnicidade.

A atual onda de celebração da etnicidade representa uma "escapatória" diante da fragmentação e da frieza da sociedade norte-americana. Nesse sentido, identidades étnicas estão sendo reinventadas para preencher a 
necessidade de que "nossos pés possam pisar num chão mais seguro", familiar e caloroso porque traz um passado no qual era possível olhar o mundo com olhos de criança. Isto é particularmente importante na medida em que os produtos especificamente dirigidos para segmentos étnicos se apresentam como uma alternativa ao caos produzido pelo consumo de massa.

Apesar de ligado à imigração, o fenômeno que a autora descreve não se encontra concentrado em guetos ou enclaves étnicos das metrópoles norte-americanas. Associadas ao marketing, as questões ligadas à etnicidade estão atraindo a atenção de uma parcela significativa das grandes corporações. Campanhas recentes de empresas, como AT\&T e Hallmark, começam a apelar à diversidade étnica a partir dos anos 90. A AT\&T, por exemplo, estabeleceu uma série de serviços e vantagens especiais para os clientes que fazem chamadas telefônicas internacionais para parentes e amigos, por meio de uma campanha realizada em quase 20 diferentes idiomas. A Hallmark, por sua vez, na mesma década iniciou uma campanha de marketing cultural altamente bem-sucedida, colocando à venda cartões que celebram o multiculturalismo, com linhas especificamente dirigidas a judeus, afro-americanos, hispânicos, asiáticos, etc. Ainda nos anos 90, deve-se ressaltar o plano de marketing go ethnic da boneca Barbie, que, nas suas várias versões, apareceu nas prateleiras não apenas vestida de latina, African-American, indiana, asiática, etc., mas também portando características físicas distintivas desses grupos - um sucesso que fez dobrar a venda das bonecas, nas suas específicas "versões", em um ano.

Atrair um público consumidor etnicamente identificado, como se sabe, não tem sido a maneira comum de se fazer campanhas publicitárias naquele país. Ao contrário, a história da publicidade norte-americana, até recentemente, revela a ausência da representação de minorias étnicas na categoria dos consumidores. No entanto, o marketing étnico tem se tornado uma indústria capaz de desenvolver metodologias avançadas de pesquisa sobre atitudes, cultura e estilos de vida. Na última edição do The source book of multicultural experts (1999-2000), foram listadas mais de 200 firmas que trabalham com marketing étnico e multicultural. Dado o valor movimentado por esses segmentos (1 trilhão de dólares/ano), serviços financeiros têm sido igualmente atraídos para o marketing multicultural, tais como American Express, Merrill Lynch.

O que as empresas pretendem é, obviamente, aumentar suas vendas. Mas, com isso, atendem a uma demanda por produtos capazes de responder a sensibilidades étnicas enquanto necessidades específicas. A Crayola, por exemplo, aumentou seu faturamento com a linha
"Multicultural Fleshtone Crayons", mas com isso também respondeu positivamente a questões como valorização racial e auto-estima. Isto não é mera especulação. Conforme as pesquisas demonstram, os pais das crianças que compram produtos dessa linha se declaram satisfeitos pelo fato de que agora seus filhos podem desenhar figuras humanas mais parecidas com eles.

Apesar de abordar o tema de modo sofisticado (o livro não é um manual de marketing para minorias), Halter apresenta um texto acessível ao grande público, rico em informações e que, no Brasil, país escasso em estudos que abordam questões relacionadas à cultura $\mathrm{e}$ economia, abre um campo inédito de reflexão sociológica, assim como novas possibilidades de desenvolvimento de estratégias de marketing. Embora de modo tímido, também aqui algumas empresas estão começando a definir segmentos específicos de mercados promissores e lançando produtos que já podem ser encontrados nas prateleiras de supermercados e farmácias, como, por exemplo, cosméticos desenvolvidos especialmente para negros e mulatos. Portanto, Shopping for identity chega num momento oportuno.

Não se trata, entretanto, de transpor para este país modelos norte-americanos. Processos de construção e valorização de etnicidade não são socialmente relevantes entre nós. Conforme assinalado, etnicidade nos Estados Unidos está relacionada à história norte-americana e foi uma forma politicamente construída para responder aos conflitos raciais daquele país. Ainda apegado ao mito de uma suposta "democracia racial", o Brasil está longe de encarar os problemas acarretados pela nossa origem escravocrata. Mas, se, por um lado, identidades étnicas não são socialmente marcantes por aqui, por outro, é inegável que também neste país está se formando uma classe média negra com expressivo poder de consumo e que demanda produtos específicos dadas suas caraterísticas raciais. Algumas empresas vêm respondendo a essa condição, disponibilizando no mercado novos bens e serviços.

Estima-se que a classe média negra brasileira movimente cerca de 50 bilhões de reais por ano. Apesar de existirem poucos dados sobre o perfil de consumo dessa população, os negros de classe média somam 8 milhões de pessoas com renda familiar acima de 2.300 reais. Se tomarmos a publicidade como um indicador de seu potencial de consumo, basta observarmos a presença, até pouco tempo inédita, de modelos negros em comerciais recentes, anunciando produtos que variam de sabonete a fraldas descartáveis. Portanto, diferenças à parte, o livro de Halter trata de um tema que também entre nós começa a ter relevância e que merece ser investigado com maior profundidade. $\bigcirc$ 